Article

\title{
Frequency of Occurrence and Ingested Biomass of Different Prey of the Barn Owl Tyto alba in an Island Ecosystem
}

\author{
Miriam Viganò ${ }^{1}$, Leonardo Ancillotto ${ }^{2}$, Paolo Agnelli ${ }^{2}$, Gentile Francesco Ficetola ${ }^{1,3}$ \\ and Emiliano Mori $4, *$ (D) \\ 1 Department of Environmental Science and Policy, Università degli Studi di Milano, Via Celoria 26, \\ 20133 Milano, Italy; miriam.vigano@studenti.unimi.it (M.V.); francesco.ficetola@unimi.it (G.F.F.) \\ 2 Museo di Storia Naturale, Sede "La Specola", Università degli Studi di Firenze, Via Romana 17, \\ 50125 Firenze, Italy; leonardo.ancillotto@unina.it (L.A.); paolo.agnelli@unifi.it (P.A.) \\ 3 LECA, Laboratoire d'Ecologie Alpine, CNRS, Grenoble Alpes University and Savoie Mont Blanc University, \\ Rue de la Piscine 2233, F-38000 Grenoble, France \\ 4 Consiglio Nazionale delle Ricerche, Istituto di Ricerca sugli Ecosistemi Terrestri, Via Madonna del Piano 10, \\ 50019 Sesto Fiorentino (Florence), Italy \\ * Correspondence: emiliano.mori@cnr.it
}

Received: 23 November 2020; Accepted: 5 December 2020; Published: 7 December 2020

check for updates

Simple Summary: Pellets of the Barn Owl have been widely used to assess small mammal assembly in several ecosystems, and their analysis is particularly important for Mediterranean islands, where a low assembly of species may occur with respect to the mainland. In this work, we assessed the diet of the Barn Owl in Elba island (Central Italy) 30 years after the first study on this species in the same study area, through pellet analysis. Small mammals built up the staple of the diet of this raptor bird on the island, with birds being the second prey category. The presence of a skull of the Geoffroy's Myotis Myotis emarginatus confirmed the presence of this species on the island after over 60 years from the first and still unique record of the Tuscan Archipelago. Moreover, fragments of two newborn hares were detected, increasing the knowledge on the local trophic spectrum of the Barn Owl.

\begin{abstract}
The Barn Owl Tyto alba is commonly reported as a non-selective predator of small mammals, and its diet has been thoroughly analyzed also to assess the small mammal assembly composition in many study areas. The aim of this work was to analyze the diet of the Barn Owl in the Elba island through the analysis of 161 pellets collected in September 2020. Undigested fragments were isolated and compared with reference collections. We confirmed that the Barn Owl is a typical predator of field mice ( $62 \%$ of relative frequency), with synanthropic murid rodents as the second category of prey. The frequency of consumption of shrews increased by $9 \%$ with respect to the previous work, suggesting that the natural environment of Elba island is still in a good health status. Moreover, fragments of two newborn hares were detected, increasing the knowledge on the local trophic spectrum of the Barn Owl. Finally, the skull of a Geoffroy's Myotis Myotis emarginatus confirmed the presence of this species in Elba island after over 60 years from the first unconfirmed record. Repeated studies conducted in the same study site may provide useful information on prey population trends and local environmental status.
\end{abstract}

Keywords: barn owl pellets; Elba island; Myotis emarginatus; small mammal assembly; Strigiformes; trophic spectrum 


\section{Introduction}

Widespread wild species, i.e., those showing intercontinental distribution ranges, are suggested to be well-adapted to a number of different environmental conditions, which require a remarkable specific physiological plasticity [1-3]. Accordingly, the widely distributed species should be able to adapt their spatiotemporal behavior and, particularly, their diet, to different environments including different food availability and, possibly, different competitors [4-6]. Island ecosystems include most often a lower amount of potential prey species but also of intra-guild competitors with respect to the mainland, thus requiring a high adaptability by predator species [7-11].

The Barn Owl Tyto alba is a medium-sized widespread nocturnal raptor distributed in Europe, Africa, Southern Asia, Oceania, North and South America, both on mainland and on islands [12]. The diet of this species has been thoroughly studied [13], particularly in Europe [14-16] and America [17,18], given that the analyzing content of egested pellets is easy and cheap [19].

Barn Owls are mainly predators of small mammals (Rodentia and Eulipotyphla), but they may also consume bats, birds, reptiles, and insects if locally available [20-22]. Changes in the diet of this species in the same study area reflects changes in land use and in climate $[16,23,24]$. However, data on the diet of the Barn Owl in island ecosystems, particularly concerning small-sized islands, are still scanty [25-27]. It has been suggested that the Barn Owl diet includes proportionately more birds on islands than in the mainland, as islands are relatively poorer of small mammals [28]. In a review on the diet of the Barn Owl on Mediterranean islands, it has been confirmed that, although murid rodents were the commonest prey species, birds and reptiles were 5-18 more represented in the diet of insular Barn Owls with respect to those occurring on the mainland [27].

As for the Elba island, some authors only reported the occurrence of small mammals in the diet of the Barn Owl in the Tuscan Archipelago, and only showed the frequency of occurrence of small mammals, with no reference to other prey [25]. Similarly, other authors collected Barn Owl pellets on Elba islands but focused their work on the pygmy white-toothed shrew Suncus etruscus only [29]. Therefore, the only published work assessing the feeding habits of the Barn Owl in the Tuscan Archipelago reported that $91 \%$ of the diet was composed by small mammals (mostly Apodemus sylvaticus), $7 \%$ by birds, and the remaining $2 \%$ by insects [30].

Given the European decline of the Barn Owl due to pesticides and reduction of potential shelter sites [31,32], keeping the ecological knowledge of this species updated is required to better address effective conservation plans [12]. In this work, we estimated frequencies and volumes of each prey in the diet of the Barn Owl in Elba island after over 30 years since its previous assessment [30]. We predicted that small mammals will build up the staple of the diet of the Barn Owl, in line with previous review studies $[13,27]$ and that bats co-occurring within the roost of this owl species will not be included as a part of its local diet.

\section{Experimental Section}

Egested pellets were collected in the central part of the Elba island (Tuscan Archipelago, municipality of Campo nell'Elba, province of Livorno; $42.766149^{\circ} \mathrm{N}-10.246836^{\circ} \mathrm{E}$; altitude: $125 \mathrm{~m}$ a.s.1.). This hilly area is mostly covered with Mediterranean scrubland (Pistacia lentiscus L., Phyllirea spp., Smilax aspera L., Quercus ilex L., and Arbutus unedo L.). The Elba island is characterized by a Mediterranean climate (annual mean temperature: $17 \pm 7^{\circ} \mathrm{C}$; mean annual rainfall: $95 \pm 15 \mathrm{~mm}$ ), with dry summers and warm winters [24]. Apart from few wintering long-eared owls Asio otus, the Barn Owl is the largest nocturnal raptor recorded throughout the year on Elba island (databank of the Tuscan Ornithological Center, COT, Luca Puglisi, private communication 2020; www.inaturalist.org, accessed on 2 December 2020), despite the fact that its local population density has never been assessed. Apart from the European hedgehog Erinaceus europaeus, which is not included amongst potential prey species of the Barn Owl, the assembly of small mammals of the island includes the Field Mouse A. sylvaticus, the House Mouse Mus domesticus, the Black Rat Rattus rattus, the Brown Rat Rattus rattus, the Edible Dormouse Glis glis, the Lesser White-Toothed Shrew Crocidura suaveolens, and the Pygmy 
White-Toothed Shrew S. etruscus [24]. No data on the local density of small mammals and other potential prey species of the Barn Owl in the Tuscan Archipelago National Park are available.

We collected pellets in September 2020 within an abandoned cistern, where an individual of Barn Owl, several Lesser Horseshoe bats Rhinolophus hipposideros and two species of gecko (Tarentola mauritanica and Hemidactylus turcicus), all potential prey of the Barn Owl, were detected. We were not able to ascribe collected pellets to a single season, as no collection occurred at this site before our field work and after the previous work [30]. Consistently, we did not find Barn Owl pellets in any other cave, ruin, bunker, or other kinds of human settlements we visited throughout the island. Pellets were collected by hand using latex gloves and stored at $-20^{\circ} \mathrm{C}$ before analyses.

Pellets were analyzed in the laboratory through the dry methods to keep undigested materials (e.g., mandibles of small mammals and reptiles, elytras, bird beaks) well cleaned and separated from the rest of the pellet [33,34]. Food remains were then identified at the species level through a stereomicroscope (WILD M3C, Heerbrugg: 400x), by comparing them with reference collections of Museo di Storia Naturale "La Specola" and published atlases $[35,36]$. The species composition of small mammals has been detailed by [25], birds were described by [37], and reptiles by [38], whereas a complete checklist of invertebrates from the island was lacking. We computed both relative (number of occurrences of each prey species, when the present/total number of occurrences of all food remains $\times 100$ ) and absolute frequencies (i.e., the number of occurrences of each prey species, when the present/total number of pellets $\times 100$ ) of occurrence of all prey species. Biomasses of different prey were obtained from previous works (Table 1).

Table 1. Average body mass \pm standard deviation of adult individuals of prey species of the Barn Owl in Elba island.

\begin{tabular}{ccc}
\hline Species & Body Mass (Grams, Mean \pm SD) & Reference \\
\hline Apodemus sylvaticus & $28 \pm 6$ & {$[39]$} \\
Mus domesticus & $25 \pm 9$ & {$[39]$} \\
Rattus rattus & $195 \pm 21$ & {$[40]$} \\
Rattus norvegicus & $364 \pm 62$ & {$[40]$} \\
Crocidura suaveolens & $10 \pm 6$ & {$[41]$} \\
Myotis emarginatus & $12 \pm 3$ & {$[42]$} \\
Suncus etruscus & $3 \pm 1$ & {$[39]$} \\
Lepus sp.-newborns & $110 \pm 13$ & {$[39]$} \\
Passer italiae & $22 \pm 4$ & EM, unpublished data \\
Decticus albifrons & $2 \pm 1$ & University of Turin, unpublished data \\
\hline
\end{tabular}

We evaluated the total volume in the diet of each prey category by plotting absolute frequencies and volumes of each prey category in a graph, with isopleths connecting points of the same volume in the diet [43]. The trophic niche breadth was measured using the standardized Levins index ( $\mathrm{B}_{\text {sta, }}$ [44]), which ranges from 0 (minimum breadth) to 1 (maximum breadth). The standardized Levins index was computed through the formula $B_{\text {sta }}=(B-1) /(B m a x-1)$, where $B$ is the Levins index $\left(B=1 / \Sigma p_{i}{ }^{2}\right.$, where $\mathrm{p}_{i}$ is the proportion of each food item $i$ identified in every pellet), and Bmax is the total number of prey categories [44]. We calculated the Brillouin Diversity Index to determine whether our sample was large enough to reliably assess the local diet of the Barn Owl in our study area [45]. The index was computed through the formula

$$
H=\left(\ln N !-\Sigma \ln \mathrm{n}_{i}\right) / N
$$

where $H$ is the diversity index, $N$ is the total number of individual prey recorded and $\mathrm{n}_{i}$ is the number of prey items of the $i^{\text {th }}$ category [45]. The cumulative diversity $\left(\mathrm{H}_{k}\right)$ was plotted against the number of analysed pellets $(\mathrm{k})$ to determine after how many pellets an asymptote was reached, and, thus, whether the diet of Barn Owl in the study area had been adequately sampled. 


\section{Results}

We opened and analyzed a total of 161 Barn Owl pellets. The content of six of them was not determined at the species level, as it only contained non-diagnostic bones. As to our sample, the Brillouin Diversity Index indicated that 17 pellets were enough to provide the local diet of this raptor species. The average number of prey per pellet was $2.52 \pm 1.36$ (mean \pm standard deviation, $\min -\max =1-4)$. In particular, diagnostic fragments belonging to at least 399 individual prey were analyzed. The most frequent prey was A. sylvaticus (Table 2). In terms of biomass, the black rat constituted the highest percentage levels, as being the second commonest prey in frequency and one of the largest prey in the sample.

Table 2. Minimum number of individuals (Min $\mathrm{N}^{\circ}$ Ind.), relative (RF) and absolute (AF) frequencies, and biomasses of each prey category of the Barn Owl in Elba island.

\begin{tabular}{ccccc}
\hline Species & Min $\mathbf{N}^{\circ}$ Ind. & RF (\%) & AF (\%) & Biomass (\%) \\
\hline Apodemus sylvaticus & 248 & 62.16 & 100 & 39.06 \\
Rattus rattus & 45 & 11.28 & 27.95 & 50.12 \\
Rattus norvegicus & 1 & 0.25 & 0.62 & 2.05 \\
Mus domesticus & 35 & 8.77 & 21.74 & 4.92 \\
Suncus etruscus & 28 & 7.02 & 17.39 & 0.47 \\
Crocidura suaveolens & 19 & 4.76 & 11.80 & 1.07 \\
Lepus sp. & 2 & 0.50 & 1.24 & 1.24 \\
Myotis emarginatus & 1 & 0.25 & 0.62 & 0.07 \\
Passer italiae & 5 & 1.25 & 3.11 & 0.62 \\
Sturnus vulgaris & 1 & 0.25 & 0.62 & 0.45 \\
Sylviidae & 1 & 0.25 & 0.62 & 0.08 \\
Decticus albifrons & 10 & 2.51 & 6.21 & 0.10 \\
Scarabaeidae & 1 & 0.25 & 0.62 & 0.01 \\
Melolonthidae & 1 & 0.25 & 0.62 & 0.01 \\
Forficula auricularia & 1 & 0.25 & 0.62 & 0.01 \\
\hline
\end{tabular}

Consistently, Apodemus sylvaticus also accounts for the majority of the total volume in the Barn Owl diet (Figure 1), followed by rats.

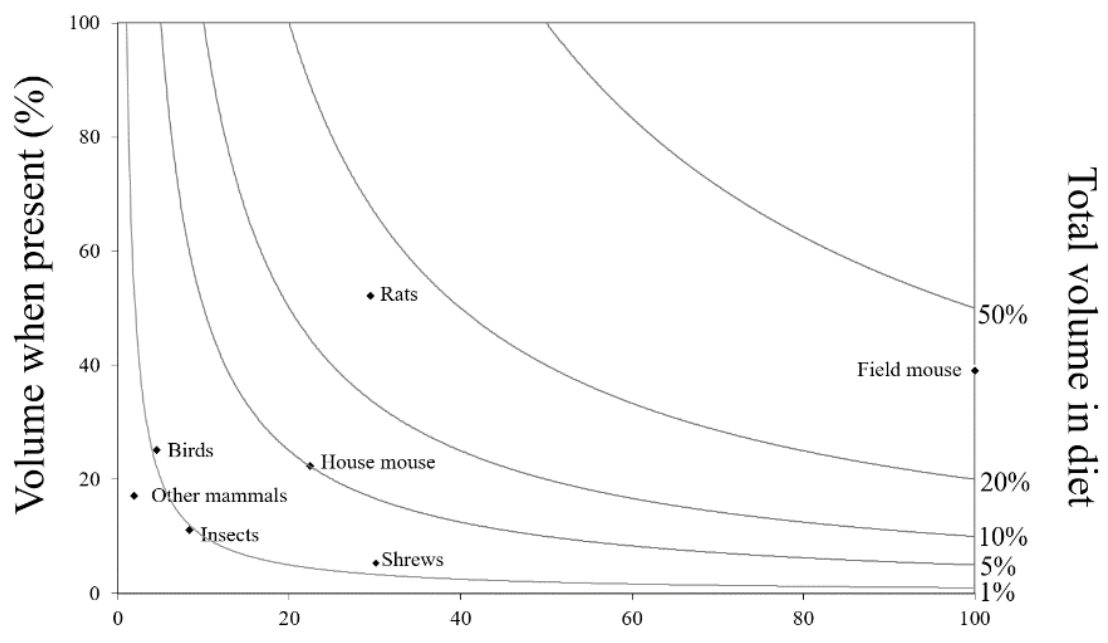

Absolute frequency (\%)

Figure 1. Diet of the Barn Owl in Elba island: Absolute frequency plotted versus volume of each food category, when present. Isopleths connect points of the same total volume in the diet. Other mammals, Lepus sp. and Myotis emarginatus; rats, Rattus rattus and R. norvegicus; shrews, Crocidura suaveolens and Suncus etruscus. 
The standardized Levins index of trophic niche amplitude was close to $0\left(\mathrm{~B}_{\mathrm{sta}}=0.12\right)$. The trophic level index of 0.14 was consistently relatively low.

\section{Discussion}

This work confirmed that the Barn Owl in the Elba island is a typical predator of wood mice A. sylvaticus, in line with our prediction, and also uses synanthropic murid rodents as the second favored prey category [30]. Apodemus sylvaticus is the dominant species within the rodent assemblage found across the Tuscan Archipelago [25], where our collection site was located. This explains its high frequency in the local diet of the Barn Owl, which is reported as a non-selective predator whose feeding habits depend on the local availability of different prey species $[13,46]$. Small mammals and mostly Murids built up the staple of its diet, as commonly reported for Mediterranean islands [25,27]. Although Barn Owls are reported to be mostly vole predators on the mainland $[27,46]$, a similar study in continental Italy at the same latitude of this work confirmed the great importance of murid rodents in the diet of this nocturnal raptor [47]. All the species of small mammals recorded in Elba island were found in Barn Owl pellets, with the exception of the edible dormouse and the hedgehog, the first being known to only occur in densely wooded areas and is only rarely represented in the diet of this raptor bird in the island (less than in 1\% pellets: [25]), the former presumably representing a challenging prey for T. alba due to its size and low palatability due to defensive spines. This confirmed that Barn Owls are not selective predators, and that they may shape their diet following the local availability of different prey species [48]. Shrews were about $9 \%$ more represented than in the previous work who collected pellets in the same area [30], who did not detect any pygmy white-toothed shrew remain in pellets. The first record of this species for the island dates back to 2008, possibly as a result of a recent accidental human-mediated introduction, and it rapidly increased up to $7 \%$ of occurrence in the local diet of the Barn Owl [29], possibly suggesting a very fast colonization and spread process by this small mammal on the island. Similarly, insect consumption was higher in our sample than previously reported [30], and was mostly represented by large-sized grasshoppers (i.e., Decticus albifrons), which may be directly preyed upon by Barn Owls [46]. These findings provide evidence of the occurrence of local good management practices [23,24]. As to birds, we detected five Italian Sparrows Passer italiae, one Starling Sturnus vulgaris and one Warbler (possibly the Dartford Warbler Sylvia undata, a species widespread in the surroundings of the collection site) in the diet of the Barn Owl, confirming a previous work, who showed that Passer sp. were the most commonly preyed birds [30]. Differently from the previous work on Elba Island [30], we did not detect any reptile in owl pellets. Consumption of birds and reptiles by owls has been suggested to be the highest in the smallest islands, where the guild of small mammals is the poorest $[25,27]$.

One skull of Geoffroy's Myotis Myotis emarginatus, and fragments of two newborn hares Lepus europaeus/corsicanus were also detected in the samples. Usually, bats are rarely consumed by Barn Owls, despite their occurrence in the diet being higher on islands (up to $0.3 \%$ ) than on the mainland [22,27]. Barn Owls often share roost sites with bats; previous works suggested that bats are mostly preyed by owls at roosting sites [49-51]. In our study area, Barn Owls shared the roost with Lesser Horseshoe Bats, whereas the species detected in pellets was the Geoffroy's Myotis, which may have been captured in flight outside the cistern, or possibly at a different roost. This bat species was only recorded on Elba island in 1956 [52], with no recent confirmation. Vergari and Dondini [53] did not find any evidence of the presence of this bat on Tuscan Archipelago, suggesting that densities could be very low. The occurrence of a skull of Geoffroy's Myotis highlights the need for further research.

The Barn Owl has never been reported as a potential predator of European Hares [54]. However, Obuch and Khaleghizadeh [55] reported the occurrence of fragments of a Cape hare Lepus capensis in one Barn Owl pellet from Iran, therefore confirming that occasional predation on lagomorphs by this raptor occurs. We detected fragments of two individual hares in two different pellets. However, mandibles were small and teeth were not yet erupted, suggesting that preyed individuals were newborns. This prevented us from assessing whether fragments belonged to the European Brown 
Hare L. europaeus or to the Apennine Hare L. corsicanus, as both species are present in the study area. Parturition of hares occurs in depressions on the surface of the ground, mostly in covered habitats, differently from rabbits who nest in burrows [39]. Leverets are active as soon as they are born and, given their low weight (around 100-110 g, [39]), they may become prey of this nocturnal raptor.

\section{Conclusions}

Despite the lack of field studies on small mammals in the Tuscan Archipelago, our work provided support to the description of the Barn Owl as a non-selective predator. Moreover, a new prey (i.e., the Hare) was added to the potential trophic spectrum of this bird. Further field work and collection of further pellets would be necessary to assess the population density of the Barn Owl in Elba island. Furthermore, a local assessment of potential prey densities should be conducted, in order to determine the prey selection by the Barn Owl. We also provided an important insight for the biogeography of a species of conservation concern, i.e., the Geoffroy's Myotis, which was only detected in the island over 60 years ago with no recent reconfirmation. A great plasticity in the diet of the Barn Owl has been proven in a high number of studies and reviews $[13,27,46]$, but long-term studies assessing diet changes are still few [14-16]. Conversely, repeated studies conducted in the same study site may provide useful information on prey population trends and the local environmental status $[13,46,48]$.

Author Contributions: Conceptualization, P.A., L.A., and E.M.; methodology, P.A.; validation, G.F.F. and P.A.; formal analysis, M.V.; investigation, M.V.; resources, P.A.; data curation, P.A. and M.V.; writing—original draft preparation, M.V.; writing — review and editing, all authors; supervision, P.A. and G.F.F. All authors have read and agreed to the published version of the manuscript.

Funding: This research received no external funding.

Acknowledgments: Authors would like to thank Giuseppe Mazza, Fabio Cianferoni, Armando Nappi, Fabio Bona, Fausto Barbagli, Luca Bartolozzi, and Filippo Maria Buzzetti who helped us in the determination of some fragments. We thank Massimo La Rosa, Francesca Giannini, and the Tuscan Archipelago National Park staff for technical support: This work has been conducted in the framework of a research project on bat fauna in Elba Island supported by the National Park. Luca Puglisi (Centro Ornitologico Toscano) provided information on nocturnal raptors on Elba island. Two anonymous reviewers and the Editor in Chief Jukka Jokimäki kindly improved our first draft with their comments.

Conflicts of Interest: The authors declare no conflict of interest.

\section{References}

1. Bai, M.L.; Schmidt, D.; Gottschalk, E.; Mühlenberg, M. Distribution pattern of an expanding Osprey (Pandion haliaetus) population in a changing environment. J. Ornithol. 2009, 150, 255-263. [CrossRef]

2. Bozinovic, F.; Calosi, P.; Spicer, J.I. Physiological correlates of geographic range in animals. Annu. Rev. Ecol. Evol. Syst. 2011, 42, 155-179. [CrossRef]

3. Hilderbrand, G.V.; Gustine, D.D.; Mangipane, B.; Joly, K.; Leacock, W.; Mangipane, L.; Erlenbach, J.; Sorum, M.S.; Cameron, M.D.; Belant, J.L.; et al. Plasticity in physiological condition of female brown bears across diverse ecosystems. Polar Biol. 2018, 41, 773-780. [CrossRef]

4. Podgórski, T.; Baś, G.; Jędrzejewska, B.; Sönnichsen, L.; Śnieżko, S.; Jędrzejewski, W.; Okarma, H. Spatiotemporal behavioral plasticity of wild boar (Sus scrofa) under contrasting conditions of human pressure: Primeval forest and metropolitan area. J. Mammal. 2013, 94, 109-119. [CrossRef]

5. Newsome, T.M.; Boitani, L.; Chapron, G.; Ciucci, P.; Dickman, C.R.; Dellinger, J.A.; Lopez-Bao, J.V.; Peterson, R.O.; Shores, C.R.; Wirsing, A.J.; et al. Food habits of the world's grey wolves. Mammal. Rev. 2016, 46, 255-269. [CrossRef]

6. Soe, E.; Davison, J.; Süld, K.; Valdmann, H.; Laurimaa, L.; Saarma, U. Europe-wide biogeographical patterns in the diet of an ecologically and epidemiologically important mesopredator, the red fox Vulpes vulpes: A quantitative review. Mammal. Rev. 2017, 47, 198-211. [CrossRef]

7. MacArthur, R.H.; Wilson, E.O. The Theory of Island Biogeography; Monographs in Population Biology; Princeton University Press: Princeton, NJ, USA, 1967; Volume 1. 
8. Jiménez, J.E.; Marquet, P.A.; Medel, R.G.; Jaksic, F.M. Comparative ecology of Darwin's fox (Pseudalopex fulvipes) in mainland and island settings of southern Chile. Rev. Chil. Hist. Nat. 1991, 63, 177-186.

9. Clevenger, A.P. Pine marten (Martes martes Linné, 1758) comparative feeding ecology in an island and mainland population of Spain. Zeitschr. Saugetierk. 1993, 58, 212-224.

10. Luiselli, L.; Filippi, E.; Capula, M. Geographic variation in diet composition of the grass snake (Natrix natrix) along the mainland and an island of Italy: The effects of habitat type and interference with potential competitors. Herp. J. 2005, 15, 221-230.

11. Stronen, A.V.; Navid, E.L.; Quinn, M.S.; Paquet, P.C.; Bryan, H.M.; Darimont, C.T. Population genetic structure of gray wolves (Canis lupus) in a marine archipelago suggests island-mainland differentiation consistent with dietary niche. BMC Ecol. 2014, 14, 11. [CrossRef]

12. BirdLife International. Tyto alba (Amended Version of 2016 Assessment). The IUCN Red List of Threatened Species 2019. 2019. Available online: https://www.iucnredlist.org/species/22688504/155542941 (accessed on 26 October 2020).

13. Romano, A.; Séchaud, R.; Roulin, A. Global biogeographical patterns in the diet of a cosmopolitan avian predator. J. Biogeogr. 2020, 47, 1467-1481. [CrossRef]

14. Love, R.A.; Webon, C.; Glue, D.E.; Harris, S.; Harris, S. Changes in the food of British Barn Owls (Tyto alba) between 1974 and 1997. Mammal. Rev. 2000, 30, 107-129. [CrossRef]

15. Milana, G.; Lai, M.; Maiorano, L.; Luiselli, L.; Amori, G. Geographic patterns of predator niche breadth and prey species richness. Ecol. Res. 2016, 31, 111-115. [CrossRef]

16. Milana, G.; Luiselli, L.; Amori, G. Forty years of dietary studies on Barn Owl (Tyto alba) reveal long term trends in diversity metrics of small mammal prey. Anim. Biol. 2018, 68, 129-146. [CrossRef]

17. Jaksic, F.M.; Seib, R.L.; Herrera, C.M. Predation by the Barn Owl (Tyto alba) in Mediterranean habitats of Chile, Spain and California: A comparative approach. Am. Midl. Nat. 1982, 107, 151-162. [CrossRef]

18. Bellocq, M.I. A review of the trophic ecology of the Barn Owl in Argentina. J. Raptor Res. 2000, 34, $108-119$.

19. Cagnacci, F.; Cardini, A.; Ciucci, P.; Ferrari, N.; Mortelliti, A.; Preatoni, D.G.; Russo, D.; Scandura, M.; Wauters, L.A.; Amori, G. Less is more: Researcher survival guide in times of economic crisis. Hystrix 2012, 23, 1-7.

20. Roulin, A.; Dubey, S. The occurrence of reptiles in Barn Owl diet in Europe. Bird Study 2012, 59, 504-508. [CrossRef]

21. Teta, P.; Hercolini, C.; Cueto, G. Variation in the diet of Western Barn Owls (Tyto alba) along an urban-rural gradient. Wilson J. Ornit. 2012, 124, 589-596. [CrossRef]

22. Roulin, A.; Christe, P. Geographic and temporal variation in the consumption of bats by European Barn Owls. Bird Study 2013, 60, 561-569. [CrossRef]

23. Roulin, A. Shrews and moles are less often captured by European Barn Owls Tyto alba nowadays than 150 years ago. Bird Study 2016, 63, 559-563. [CrossRef]

24. Roulin, A. Strong decline in the consumption of invertebrates by Barn Owls from 1860 to 2012 in Europe. Bird Study 2016, 63, 146-147. [CrossRef]

25. Amori, G.; Rizzo Pinna, V.; Sammuri, G.; Luiselli, L. Diversity of small mammal communities of the Tuscan Archipelago: Testing the effects of island size, distance from mainland and human density. Folia Zool. 2015, 64, 161-166. [CrossRef]

26. Guerra, C.; García, D.; Alcover, J.A. Unusual foraging patterns of the Barn Owl, Tyto alba (Strigiformes: Tytonidae), on small islets from the Pityusic archipelago (Western Mediterranean Sea). Folia Zool. 2014, 63, 180-187. [CrossRef]

27. Janžekovič, F.; Klenovšek, T. The biogeography of diet diversity of Barn Owls on Mediterranean islands. J. Biogeogr. 2020, 47, 2353-2361. [CrossRef]

28. Johnston, D.W.; Hill, J.M. Prey selection of common Barn Owls on islands and mainland sites. J. Raptor Res. 1987, 21, 3-7.

29. Szpunar, G.; Aloise, G.; Filippucci, M.G. Suncus etruscus (Soricomorpha, Soricidae): A new species for Elba island (Tuscan Archipelago, Italy). Ital. J. Zool. 2008, 75, 445-447. [CrossRef]

30. Contoli, L.; Aloise, G.; Filippucci, M.G. Sulla nicchia trofica di Tyto alba ed Athene noctua nell'isola d'Elba (Toscana) in rapporto all'Italia tirrenica. Bull. Ecol. 1988, 19, 367-373.

31. Martínez, J.A.; Zuberogoitia, I. Habitat preferences and causes of population decline for Barn Owls Tyto alba: A multi-scale approach. Ardeola 2004, 51, 303-317. 
32. Roulin, A. Spatial variation in the decline of European birds as shown by the Barn Owl Tyto alba diet. Bird Study 2015, 62, 271-275. [CrossRef]

33. Cassola, F.; Lovari, S. Food habits of rollers during the nesting season. Boll. Zool. 1979, 46, 87-89. [CrossRef]

34. Nappi, A. L'analisi delle borre degli uccelli: Metodiche, applicazioni e informazioni. Un lavoro monografico. Picus 2011, 37, 106-120.

35. Nappi, A. I Micromammiferi d'Italia; Simoni, Ed.; Simoni: Naples, Italy, 2001.

36. Gaggi, A.; Paci, A.M. Atlante degli Erinaceomorfi dei Soricomorfi e dei Piccoli Roditori dell'Umbria; Dimensione Grafica Snc.: Spello (Perugia), Italy, 2014.

37. Di Carlo, E.A. Avifauna delle Isole dell'Arcipelago Toscano. Le forme ornitiche insulari. Biogeographia 1976, 5, 845-878. [CrossRef]

38. Vaccaro, A.; Turrisi, G.F. Ritrovamento di Zamenis longissimus (Laurenti, 1768) (Reptilia, Colubridae) sull'Isola d'Elba (Toscana, Italia). Acta Herpetol. 2007, 2, 59-63.

39. Amori, G.; Contoli, L.; Nappi, A. Mammalia II: Erinaceomorpha, Soricomorpha, Lagomorpha, Rodentia Il Sole 24 Ore; Edagricole Calderini: Bologna, Italy, 2008.

40. Mori, E.; Iacucci, A.; Castiglia, R.; Santini, L. Sexual-size dimorphism in two synanthropic rat species: Comparison and eco-evolutionary perspectives. Mammal. Biol. 2017, 83, 78-80. [CrossRef]

41. Mori, E.; Brambilla, M.; Ramazzotti, F.; Ancillotto, L.; Mazza, G.; Russo, D.; Amori, G.; Galimberti, A. In or out of the checklist? DNA barcoding and distribution modelling unveil a new species of Crocidura shrew for Italy. Animals 2020, 12, 380. [CrossRef]

42. Hutson, A.M.; Spitzenberger, F.; Aulagnier, S.; Nagy, Z. Myotis emarginatus. IUCN RedList Data. 2008. Available online: https://www.iucnredlist.org/species/14129/22051191 (accessed on 3 November 2020).

43. Levins, R. Evolution in Changing Environments; Princeton University Press: Princeton, NJ, USA, 1968.

44. Kruuk, H. The Social Badger: Ecology and Behaviour of Group Living Carnivore (Meles meles); Oxford University Press: Oxford, UK, 1989.

45. Glen, A.S.; Dickman, C.R. Diet of the spotted-tailed quoll (Dasyurus maculatus) in Eastern Australia: Effects of season, sex and size. J. Zool. 2006, 269, 241-248. [CrossRef]

46. Taylor, I.R. Barn Owls: Predator-Prey Relationships and Conservation; Cambridge University Press: Cambridge, UK, 1994.

47. Mori, E.; Ferretti, F.; Fattorini, N. Alien war: Ectoparasite load, diet and temporal niche partitioning in a multi-species assembly of small rodents. Biol. Invasions 2019, 21, 3305-3318. [CrossRef]

48. Saufi, S.; Ravindran, S.; Hamid, N.H.; Abidin, C.M.R.Z.; Ahmad, H.; Ahmad, A.H.; Salim, H. Diet composition of introduced Barn Owls (Tyto alba javanica) in urban area in comparison with agricultural settings. J. Urban Ecol. 2020, 1, 1-8.

49. Ruprecht, A.L. Bats (Chiroptera) as constituents of the food of Barn Owls Tyto alba in Poland. Ibis 1979, 121, 489-494. [CrossRef]

50. Lewis, S.E. Low roost-site fidelity in pallid bats: Associated factors and effect on group stability. Behav. Ecol. Sociobiol. 1996, 39, 335-344. [CrossRef]

51. Lesiński, G.; Kasprzyk, K.; Gryz, J. Bats taken by the tawny owl in relation to its roosting site. North-West J. Zool. 2012, 8, 247-251.

52. Kahmann, H.; Goerner, P. Les chiroptères de Corse. Mammalia 1956, 20, 333-389. [CrossRef]

53. Vergari, S.; Dondini, G. La Chirotterofauna dell'Arcipelago Toscano; WWF Toscana, Ed.; WWF Toscana: Roma, Italy, 1998.

54. Fattorini, N.; Burrini, L.; Morao, G.; Ferretti, F.; Romeo, G.; Mori, E. Splitting hairs: How to tell hair of hares apart for predator diet studies. Mammal. Biol. 2018, 85, 84-89. [CrossRef]

55. Obuch, J.; Khaleghizadeh, A. Spatial variation in the diet of the Barn Owl Tyto alba in Iran. Podoces 2011, $6,103-116$

Publisher's Note: MDPI stays neutral with regard to jurisdictional claims in published maps and institutional affiliations. 